УДК 159.942 - 053.6

Ю. І. КОНОПЛІЦЬКА, О. Г. СТАВИЦЬКА

\title{
ОСОБЛИВОСТІ РОЗВИТКУ ЕМОЦІЙНГО ІНТЕЛЕКТУ У ПІДЛІТКОВОМУ ВІЦІ
}

Стаття присвячена теоретичному аналізу особливостей розвитку емоційного інтелекту у підлітковому вічі. Здійснюється загальна характеристика структури, етапів розвитку та становлення емоиійного інтелекту. Проводиться оиінка та визначення відмінностей між високим та низьким рівнем управління власними емоціями. У роботі робиться акиент на підлітковому віці, адже ие є сенситивний період формування емочійного інтелекту, де особистість вчиться управляти власними емоціями та емоціями інших людей. Вікові особливості підліткового періоду сприяють становленню внутрішньоособистого та міжособистісного емоційного інтелекту у рамках провідної 
діяльності та соиіальної ситуації розвитку підлітка, тому питання гармонійної єдності емоцій та когнітивних процесів є як ніколи актуальним саме у иъьому віцฺі.

Ключові слова: емоції, емоційний інтелект (EQ), коефіцієнт інтелекту (IQ), міжособистісний інтелект, внутрішньоособистісний інтелект, особистість, підлітковий вік.

Статья посвящена теоретическому анализу особенностей развития эмоционального интеллекта в подростковом возрасте. Осуществляется общая характеристика структуры, этапов развития и становления эмоционального интеллекта. Проводится оценка и определение различий между высоким и низким уровнем управления собственными эмоциями. В работе делается акиент на подростковом возрасте, ведь это сенситивный период формирования эмочионального интеллекта, где личность учится управлять собственными эмоциями и эмоциями других людей. Возрастные особенности подросткового периода способствуют становлению внутриличностного и межличностного эмоционального интеллекта в рамках ведущей деятельности и соииальной ситуачии развития подростка, поэтому вопрос гармоничного единства эмоций и когнитивных процессов является как никогда актуальным именно в этом возрасте.

Ключевые слова: эмочии, эмочиональный интеллект (EQ), коэффициент интеллекта (IQ), мижличностный интеллект, внутриличностный интеллект, личность, подростковый возраст.

Постановка проблеми. Питання розвитку емоційного інтелекту досить нове та важливе, особливо для молоді в умовах глобалізації сучасного суспільства. Проте, на сьогоднішній день, немає чітко розробленої теорії визначення емоційного інтелекту та недостатньо вивчена його роль серед інших психологічних структур особистості. Саме тому зараз зростає актуальність такого поняття як «емоційний інтелект» - EQ. Таким чином, учені позначають здатність людини розуміти й контролювати свої емоції та емоції оточуючих. Вважається, що ЕQ є набагато важливішим фактором, який сприяє успіху людини, ніж «звичайний» інтелект - IQ. На відміну від IQ, рівень якого багато в чому визначений генетично, рівень EQ залежить від зусиль самої людини [10]. Емоційний інтелект дозволяє нам «інтелектуально» керувати своїм емоційним життям. А як відомо, сенситивним періодом розвитку EQ $є$ саме підлітковий вік, у рамках якого особливо зростає необхідність розуміння і управління емоційною сферою. Роль усвідомлення власних емоцій та емоцій інших людей зростає, адже саме у цей період існує висока потреба у кращому розумінні себе та оточуючих. Отож, проблема емоційного інтелекту має практичну значущість i до сьогоднішнього дня залишається недостатньо дослідженою як у теоретичному плані, так і в експериментальному, через те і потребує наукового вивчення та пояснення.

Аналіз останніх досліджень i публікацій. Емоційний інтелект став предметом психологічного дослідження порівняно недавно завдяки працям зарубіжних науковців Г. Гарднера, Д. Гоулмана, Д. Карузо, Дж. Майєра, П. Саловея. Дослідники вважали, що емоційний інтелект є основою професійного та особистого успіху особистості. Американський психолог Г. Гарднер дав поштовх до виникнення нової концепції емоційного інтелекту, адже він був першим, хто почав говорити про множинність форм прояву інтелекту [16]. Г. Гарднер вважав, що внутрішньоособистісний інтелект є ключем до самопізнання, до розуміння власних емоцій і почуттів 3 метою управління своєю поведінкою. Міжособистісний інтелект - це здатність розуміти інших людей, ефективно з ними взаємодіяти. У працях американських психологів Дж. Майєра і П. Саловея вперше був вжитий термін «емоційний інтелект» та розпочалась дослідницька діяльність щодо його вивчення. Емоційний інтелект, на думку цих учених, $\epsilon$ сукупністю когнітивних здібностей до ідентифікації, розуміння та управління емоціями [18]. Проте, особливий інтерес до емоційного інтелекту зріс завдяки працям Д. Гоулмана, який вважав, що наш успіх визначається загальним інтелектом лише на $20 \%$, все інше припадає на долю інших факторів, котрі забезпечують успіх. Серед них значне місце належить емоційному інтелекту, який сприяє особистісному зростанню, ефективності професійної діяльності та кар'єрі людини [17]. Теоретико-методологічні підходи до проблеми співвідношення інтелектуального й емоційного розглядали у своїх роботах Б.Г. Ананьєва, Л.С. Виготського, С.Л. Рубінштейна, О.М. Леонтьєва, В.М. М'ясищева, О.К. Тихомирова та інші. Зокрема, видатний психолог Л.С. Виготський виділяв серед найважливіших питань психології проблему єдності афекту та інтелекту [3]. У наш час на пострадянському просторі проблема емоційного інтелекту активно обговорюється і висвітлюється у працях таких вчених: І.М. Андрєєвої, О.І. Власової, С.П. Дерев'янко, Г.Г. Гарскової, Н.В. Ковриги, Д.В. Люсіної, М.О. Манойлової, Е.Л. Носенко. 
Мета статті. Здійснити теоретичний аналіз досліджень особливостей розвитку емоційного інтелекту у підлітковому віці. Дослідити підлітковий вік як найважливіший етап становлення внутрішньоособистісного та міжособистісного інтелекту особистості.

У відповідності із поставленою метою були визначені наступні завдання дослідження: здійснити науково - теоретичний аналіз досліджень розвитку емоційного інтелекту у підлітковому віці; сформувати платформу для розробки програм його стимулювання.

Виклад основного матеріалу дослідження. Цікавість до емоційного інтелекту (EQ) зараз зростає у всьому світі. Думка Д. Гоулмена про те, що лідерство та успішність зачіпає наші емоції і часто визначається ними, дійсно приймається до уваги багатьма науковцями. Саме динаміка сьогодення викликає гостру потребу у розвитку емоційного інтелекту за для ефективної соціалізації індивіда та успішної його самореалізації. Коефіцієнт IQ характеризує можливості людини оперувати інформацією, логічними правилами, схемами. І це важливо для особистості, але недостатньо для того, щоб бути успішною. Потрібно мати розвинений $\mathrm{EQ}$, який дозволяє зрозуміти власні переживання та стани інших людей, налагоджувати взаємодію із оточуючими, легко адаптуватися до нового середовища та управляти своєю емоційною сферою [2]. Адже кожного дня із нами відбувається маса подій та ситуацій, які викликають певний емоційний стан, яким потрібно вчитися управляти.

Емоційний інтелект (EQ) характеризують як сукупність здібностей, що дають можливість особистості усвідомлювати й розуміти як власні емоції, так і емоції інших людей. Люди з високим рівнем розвитку емоційного інтелекту здатні керувати своєю емоційною сферою, їхня поведінка більш гнучка, тому вони 3 більшою легкістю досягають поставлених цілей шляхом взаємодії 3 іншими людьми. Саме емоційний інтелект пояснює, чому іноді випускники вищих навчальних закладів з середнім рівнем знань будують кар'єру, а відмінники часто не досягають професійних злетів, тому існування в людини IQ не є повною гарантією успіху [15]. Розвиток емоційний інтелекту (EQ) проходить у декілька важливих етапів. Спочатку особистості важливо усвідомлювати свої емоції, розуміти, що і як я переживаю. Далі важливо навчитися управляти власними емоціями, визначати причину та корінь переживань. Третій етап передбачає зчитування і усвідомлення того, що переживають і відчувають оточуючі. I на завершальному етапі важливо навчитися управляти емоціями інших людей завдяки власній емпатії, соціальній чуйності та вмінні цілеспрямовано впливати на людину [14]. Високий емоційний інтелект дає гармонію між емоціями і розумом, але для цього варто спочатку прийняти відповідальність за себе, свої потреби та мотиви, а відповідно і за свої емоції. Низький емоційний інтелект характеризується нестабільністю, наявністю страхів, фрустрацій, провини і депресії. Будь - яка ситуація для людини, особливо негативна, виражається через яскраву тривожність, тривале обдумування ситуації, переживання ненависті, агресії та гніву. I все це $\epsilon$ ознакою низько емоційного інтелекту, де людина постійно «застрягає» на емоціях, що впливає на іiі самопочуття, мислення, працездатність та на загальний емоційний стан.Також емоційний інтелект включає у себе два важливі компоненти. Внутрішньоособистісний компонент характеризується такими складовими як: самооцінка, оптимізм, упевненість у собі, гнучкість, відповідальність. Міжособистісний компонент включає: толерантність, емпатія, відкритість, діалогічність, вміння легко налагоджувати контакт із людьми.

На сьогоднішній час вчених цікавить питання формування емоційного інтелекту в онтогенезі, адже емоційна сфера зазнає значних змін у ході дорослішання людини. Визнається, що саме підлітковий вік $є$ найбільш цікавим, адже це перехідний період між дитинством та дорослістю. Він найбільш складний не лише для взаємодії з оточуючими, а й для самої особистості.

Для емоційної сфери підлітків найбільш характерні:

- досить велика емоційна збудливість, а тому підлітки відрізняються дратівливістю, бурхливим проявом своїх почуттів, пристрастю: вони із великим бажанням беруться за цікаву справу, пристрасно відстоюють свої погляди, обурюються через будь - яку несправедливість до себе чи своїх друзів;

- велика стійкість емоційних переживань у порівнянні із молодшими школярами; зокрема, підлітки довго не забувають образ;

- характерне очікування страху; за дослідженнями В.М. Кисловської, саме у підлітковому віці спостерігається найвищий рівень тривожності;

- суперечливість почуттів: досить часто підліток захищає свого друга, розуміючи його неправоту; володіючи розвинутим почуттям гідності вони можуть заплакати від образи, хоч плакати соромно;

- виникають переживання не тільки щодо оцінювання їх іншими людьми, але і щодо самооцінки, оскільки у цьому віці відбувається розвиток самосвідомості; 
- досить сильно розвинуте почуття прив'язаності до групи, а тому вони боляче переживають осуд товаришів, ніж осуд дорослих чи вчителя; спостерігається у цьому віці страх бути невизнаним групою;

- висока вимогливість до дружби, в основі якої лежить не спільна гра, як у молодших школярів, а спільність інтересів, моральних почуттів;

- дружба у підлітків більш вибіркова і інтимна, більш тривала.

Науковці наголошують, що підлітковий вік - це найбільш складний і бурхливий період у формуванні особистості дитини, який характеризується глибокими змінами в соціальному, психологічному та емоційному розвитку, що насамперед пов'язано із фізіологічною перебудовою організму, зумовленою статевим дозріванням [12]. Доведено, що новоутворенням підліткового віку $є$ самосвідомість, яка веде до формування почуття дорослості. Саме це зумовлює особливості емоційної поведінки. У цей період дитина вимагає визнання власної індивідуальності та рівності із дорослим. Криза супроводжується емоційними відхиленнями у поведінці, спалахами агресії та непокори. Водночас, зростає необхідність розуміння емоцій інших людей та управління власними емоціями, оскільки провідною діяльність стає інтимно - особистісне спілкування з однолітками [7; 8].

Стосовно особливостей розвитку емоційного інтелекту, то більшість науковців стверджують, що в підлітковому віці збільшується кількість емоціогенних об'єктів, які переважно мають соціальний характер, а відтак знання про емоції стають усе більше опосередкованими. Ю. В. Давидова наголошує, що EQ має складну будову: зовнішній аспект, або «розуміння емоцій» $\mathrm{i}$ внутрішній аспект, або «емоційна саморегуляція» [5]. Основні функції емоційного інтелекту, на думку автора, полягають у забезпеченні успішної діяльності, а також гармонізації процесів внутрішньоособистісної та міжособистісної взаємодії. О. І. Власова у власному дослідженні встановила, що до кінця підліткового віку розвиток емоційно - когнітивної здібності фактично досягає середніх нормативних показників дорослої людини [4, с. 280-281]. Відбувається становлення емоційного самоусвідомлення, зокрема найбільші результати розвитку виявлено в показниках розрізнення і диференціації емоцій.

Проблема емоційної зрілості розглядається І. Г. Павловою [10]. Дослідниця стверджує, що у віці 13 - 14 років суттєво покращується здатність керування підлітками власних емоцій, а в період 3 14 до 15 років - підвищується рівень довільності вираження емоцій у спілкуванні. Також виявлено, що дівчатка $є$ більш співчутливими та емпатійними, вони краще ніж хлопчики, відчувають емоції інших людей. Тому можна сказати, що у підлітковому віці продовжується процес становлення емоційного інтелекту відбуваються зміни, які мають як позитивний, так і негативний характер. Для підлітка дуже важливим стає спілкування із друзями, однокласниками. Саме у цьому середовищі дитина порівнює, наслідує, вчиться керувати власними емоційними поривами та відчувати оточуючих йому людей. Формування емоційної сфери у підлітковому віці порівняно із дитинством має певні відмінні риси, адже це період, під час якого підліток виражає, пізнає та формує себе. Зміни в пізнавальній та емоційній сфері підлітка відбуваються під впливом таких соціально психологічних чинників: соціально - конституціональних характеристик (гендер, вік), інтелектуального розвитку, розвитку емоційної сенситивності, соціальної взаємодії, освіти та самоосвіти. Чинник соціальної взаємодії включає відносини в сім’ї, шкільному колективі, 3 учителями, однолітками. I добре розвинений EQ є важливою умовою для формування адаптивної поведінки підлітка серед оточуючих. Індивіди 3 високим рівнем емоційного інтелекту характеризуються вираженими здібностями до розуміння емоцій (власних та інших людей), прояву емоцій та управлінням емоційною сферою, що зумовлює більш високу адаптивність та ефективність у спілкуванні та діяльності [1, с. 25-30]. Низький рівень EQ підлітка тісно пов'язаний з соціальною дезадаптацією і різноманітними емоційними та поведінковими розладами.

Емоційний інтелект не є іманентним і може розвиватися, вдосконалюватися, зростати. Інтегрованим відображенням внутрішніх детермінант EQ у свідомості людини можна вважати почуття психологічного благополуччя, у якому фіксується позитивне ставлення особистості до себе як суб'єкта життєдіяльності [9, с. 87]. Проблема розвитку емоційного інтелекту є актуальною саме для підліткового віку, адже це період, коли дитина знаходиться між потребою у інтимно особистому спілкуванні одночасно і бажанням самоствердитися та проявити себе. Тим самим, підліток намагається управляти своїми емоціями за для ефективної взаємодії із іншими і одночасно у дитини проявляється довільність у їі поведінці та вираженні власних емоцій.

Висновки та перспективи подальших досліджень. Емоційний інтелект $є$ головною складовою у досягненні максимального відчуття щастя та успішної самореалізації. EQ - необхідний чинник активізації розумової вправності, оскільки визнання своїх почуттів і керування ними в 
конструктивний спосіб збільшує інтелектуальні сили особистості. Отже, емоційний інтелект є тією сполучною ланкою, що допомагає осмислити міжособистісні взаємини на основі розуміння емоцій та почуттів суб'єктів взаємодії, вибудовувати лінію поведінки в потрібному річищі, що в свою чергу, призводить до максимально комфортного співіснування в соціумі та допомагає домагатися поставлених цілей під час конструктивної взаємодії 3 іншими людьми. Підлітковий період $\epsilon$ сенситивним періодом розвитку емоційного інтелекту, адже у цей час складаються сприятливі передумови до розвитку внутрішньоособистого інтелекту, а також соціальна ситуація розвитку зумовлює необхідність розвитку ще й міжособистісного інтелекту.

А тому, для розвитку емоційний інтелект підлітка, важливо використовувати цілеспрямоване навчання за для ефективного поєднання когнітивних функцій та емоційної сфери.

\section{Список використаних джерел}

1. Бантишева О. О. Взаємозв'язок емоційного інтелекту зі схильністю осіб юнацького віку до віктимної поведінки / О. О. Бантишева // Вісник ЧДПУ ім. Т. Г. Шевченка. - 2014. - С. 25-30.

2. Бурлачук Л. Ф. Психодиагностика : учебник / Л. Ф. Бурлачук. - СПб. : Питер, 2006. - 351

c.

3. Выготский Л. С. Мышление и речь / Л. С. Выготский // Собрание сочинений : в 6 т. / Л. С. Выготский ; под ред. В. В. Давыдова. - Москва: Педагогика, 1982. - Т. 2. Проблемы общей психологии. - С. 5-361.

4. Власова О. І. Психологія соціальних здібностей: структура, динаміка,чинники розвитку : монографія / О. І. Власова. - Київ, 2005. - 308 с.

5. Давыдова Ю. В. Эмоциональный интеллект: сущностные признаки, структура и особенности проявления в подростковом возрасте : автореф. дисс. ... канд. психол. наук / Ю. В. Давыдова. - Москва, 2011. - 22 с.

6. Андреева И.Н. Эмоциональный интеллект как феномен современной психологии / И. Н. Андреева. - Новополоцк : ПГУ, 2011. - 388 с.

7. Заброцький М. М. Вікова психологія : навч. посіб. / М. М. Заброцький. - Київ : МАУП, 1998. $-88 \mathrm{c}$.

8. Кутішенко В. П. Вікова та педагогічна психологія: (курс лекцій) : навч. посіб. для студентів вищ. навч. закл. / В. П. Кутішенко ; М-во освіти і науки України. Ін-т соц. роботи та упр. НПУ ім. М. П. Драгоманова. - Київ : Центр навч. літ., 2005. - 128 с.

9. Носенко Е. Л. Емоційний інтелект : концептуалізація феномена, основні функції : монографія / Е. Л. Носенко, Н. В. Коврига. - Київ : Вища шк., 2003. - 126 с.

10. Павлова І. Г. Становлення емоційної зрілості в підлітковому та юнацькому віці : автореф. дис. ... канд. психол. наук : 19.00.07 / І. Г. Павлова. - Одеса, 2005. - 19 с.

11. Практический интеллект / [Д. Стенберг, Б. Форсайт, Д. Хедланд и др.]. - СПб. : Питер, 2002. $-272 \mathrm{c}$.

12. Психология подростка : [учебник] / под ред. А. А. Реана. - СПб. : Прайм-ЕВРОЗНАК, 2003. $-480 \mathrm{c}$.

13. Рейковский Я. В. Экспериментальная психология эмоций / Я. В. Рейковский. - М. : Прогресс, 1979. - С. 133-179.

14. Филатова О. Эмоциональний интеллект как показатель целостного развития личности / О. Филатова // Персонал. - 2000. - № 5. - С. 100-103.

15. Фетискин Н. П. Социально-психологическая диагностика развития личности и малых групп : [учеб. пособ.] / Н. П. Фетискин, В. В. Козлов, Г. М. Мануйлов. - М. : Ин-т психотерапии, 2005. $-337 \mathrm{c}$

16. Gardner H. Multiple intelligences: the theory in practice / H. Gardne. - New York : Basic Books, 1993. $-304 \mathrm{p}$.

17. Goleman D. Emotional intelligence / D. Goleman. - New York : Bantam Books, 1995. - 352 p.

18. Mayer J. D. The Intelligence of emotional intelligence / J. D. Mayer, P. Salovey // Intelligence. - 1993. - V. 17, № 4. - P. 433-442.

\section{References}

1. Bantysheva O. O. Interrelation of emotional intelligence with the tendency of persons of juvenile age to victimal behavior / O. O. Bantysheva // Herald of the ChSPU them. T.G. Shevchenko, 2014 227 pp. - pp. $25-30$

2. Burlachuk L.F. Psychodiagnostics / L.F. Burlachuk - SPb.,: "Peter", 2002. - P. 67-69 
3. Vygotsky, L.S. Thinking and Speaking: Collected. op. : in 6 tons / L.S. Vygotsky. - M.: Pedagogy, 1982. - T.2. - 5-361 p.

4. Vlasova O.I. Psychology of social structures: structure, dynamika, chinniki rozvitku: / Vlasova O. I., 2005. - 40 p.

5. Davydova Yu.V. Emotional intelligence: essential features, structure and features of manifestation in adolescence: the author's abstract. dis. on the basis of science. stepping cand. crazy. Sciences / Davydova Yu. V., 2011. - 22 p.

6. Emotional intelligence as a phenomenon of modern psychology / IN Andreeva. - Novopolotsk: PGU, 2011. -388 p.

7. Zabrotsky M.M. Vikova psychology / M.M. Zabrotsky., 1998. - 92 p.

8. Kutishenko VP P. Vikova te pedagogicna psikhologii (course lecture) / V. P. Kutishenko., 2005. $-128 \mathrm{p}$.

9. Nosenko EL Emotion and telecommunication: conceptualization of the phenomenon, basic functions: monogr. / E. L. Nosenko, N. V. Kovriga. it is Kyiv: Higher school, 2003. - 126p.

10. Pavlova I. G. Stanovlennya emotsionnoi zrilosti in pidlitkovomu ya junatskomu vitsi: the author's abstract. dis. on the basis of science. stepping cand. crazy. Sciences: spec. 19.00.07 / Pavlova I. G. Odesa, 2005. - 19 p.

11. Practical intelligence / [D. Stenberg, B. Forsythe, D. Hedland Ta in.]. - Peter, 2002. - 272 with.

12. Psychology of a teenager: [textbook] / ed. A.A. Reana. - St. Petersburg. : Prime-EVROZNAK, 2003. -480 with.

13. Reikovsky YV Experimental psychology of emotions / Ya. V. Reikovsky. - M.: Progress, 1979. P. 133-179.

14. Filatova O. Emotional intellect as an indicator of the integral development of personality / O. Filatova // Staff. - No. 5. - 2000. - P. 100-103.

15. Fetiskin, NP Social and psychological diagnosis of personality development and small groups [Proc. pos.] / H. P.Fetiskin, V.V. V. Kozlov, GM Manuilov - / N.P. Fetiskin, V.V. Kozlov, G.M. Manuilov. Moscow: Institute of Psychotherapy, 2005. - P. 57

16. Gardner H. Multiple intelligences: the theory in practice / H. Gardne. - New York : Basic Books, 1993. -304 p.

17. Goleman D. Emotional intelligence / D. Goleman. - New York : Bantam Books, 1995. -352 p.

18. Mayer J.D., Salovey P. The Intelligence of emotional intelligence / J.D. Mayer, P. Salovey // Intelligence. - 1993. - V.17. - № 4. - P. 433-442.

\section{Y. I.Konoplitska, O. G. Stavitska PECULIARITIES OF EMOTIONAL INTELLIGENCE DEVELOPMENT DURING ADOLESCENCE.}

The article is dedicated to the theoretical analysis of the peculiarities of emotional intelligence development during adolescence. It provides general characterization of the structure, development stages, and formation of emotional intelligence. The article carries out assessment and definition of the differences between high and low levels of personal emotions control. The work lays emphasis on adolescence since this is a sensitive period of emotional intelligence formation, when a person learns controlling their own emotions and emotions of others. Age peculiarities of adolescence support the formation of intrapersonal and interpersonal emotional intelligence within the adolescent's leading activity and social situation of development; therefore, the issue of harmonious unity between emotions and cognitive processes is more than ever important specifically in this age.

Key words: emotions, emotional intelligence (EQ), coefficient of intelligence (IQ), interpersonal intelligence, intrapersonal intelligence, personality, adolescent age. 